\title{
Milk adulteration: Detection of bovine milk in bulk goat milk produced by smallholders in northeastern Brazil by a duplex PCR assay
}

\author{
N. P. A. Rodrigues, ${ }^{\star}$ P. E. N. Givisiez,† R. C. R. E. Queiroga, ${ }^{\star}$ P. S. Azevedo,† W. A. Gebreyes, $¥ \S$ \\ and C. J. B. Oliveirat $\S^{1}$ \\ *Department of Nutrition, Federal University of Paraíba, João Pessoa-PB, 58059-900, Brazil \\ †Department of Animal Science, Federal University of Paraíba, Areia-PB, 58397-000, Brazil \\ ‡Department of Veterinary Preventive Medicine, College of Veterinary Medicine, The Ohio State University, Columbus 43210 \\ §Veterinary Public Health-Biotechnology Global Consortium (VPH-Biotech), The Ohio State University, Columbus 43210
}

\section{ABSTRACT}

The aim of this study was to investigate the adulteration of goat milk produced by smallholders in semiarid northeastern Brazil with bovine milk as an adulterant. The study was requested by the association of smallholder producers in the region to investigate and to inhibit adulteration practices as a need to ensure the quality and safety of goat milk. A duplex PCR assay has been developed and standardized. Further validation was performed in 160 fresh bulk goat milk samples. The detection limit of the duplex PCR was $0.5 \%$ bovine milk in goat milk and the results indicated that $41.2 \%$ of the goat milk presented to market was positive for bovine milk. Making the test available to the association of producers, together with extension activities, have been applied to reduce adulteration in goat milk sold to small-scale dairy plants and to ensure the species origin for goat milk in the state of Paraíba.

Key words: dairy, goat, milk adulteration, PCR

\section{INTRODUCTION}

The quality of raw milk is critical to the success of the dairy industry worldwide. In addition to scientific information showing the effect of microbiological and physicochemical traits on the quality of pasteurized milk and dairy products, social and economic aspects have triggered important changes in the dairy industry worldwide. The globalization of the food supply and the increased demand of consumers for safe food have led to large investments in research and implementation of quality assurance programs to boost market competitiveness, reliability, and product safety. However, the dairy production chain in certain developing regions

Received December 6, 2011

Accepted January 1, 2012.

${ }^{1}$ Corresponding author: celso.oliveira@pq.cnpq.br still faces many challenges related to quality and safety of raw milk to support its consolidation and meet consumer needs. This is the current scenario of the goat milk chain in northeastern Brazil. Goat milk production has a very important economic role in the semiarid part of Paraíba State. Although the productivity of the goat milk industry in this region is low compared with worldwide developed regions or even with intensive systems in southern Brazil, this is currently the main goat production region in Brazil and is responsible for approximately $20 \%$ of the total Brazilian goat milk production. Around 19,000 L daily are produced by 1,500 smallholders in Paraíba. The goat milk chain plays an important role in the social aspect, as the family-based system employs a large number of individuals and often is the primary income for the families. Furthermore, government investment has led to important changes in the production systems. Producers are organized in associations and currently 8 small-scale dairy plants exist for the pasteurization of goat milk. The majority of pasteurized milk is bought by the federal government and distributed to public schools and day care centers within social programs designed to reduce poverty, such as Fome Zero (No Hunger).

However, the major goal of the associations of smallholder producers is to access the private market and, therefore, efforts have been applied to ensure milk quality. This study was developed because the association of producers suspected that the practice of adding bovine milk in bulk goat milk by some producers was common and asked for a test that would be able to detect adulteration. Such practice was supposedly done by some producers with the goal of maximizing their profits, considering the higher market value of goat milk. Therefore, the aims of this investigation were to assess the occurrence of bovine milk in bulk goat milk produced by smallholders in the semi-arid region of Paraíba State, and to make available a laboratory test to support monitoring programs of the goat milk chain in the region. 
Table 1. Primers used in the duplex PCR targeting goat and bovine DNA sequences in milk

\begin{tabular}{llclc}
\hline & $\begin{array}{l}\text { GenBank } \\
\text { accession } \\
\text { number }\end{array}$ & $\begin{array}{c}\text { Location in the } \\
\text { mitochondrial } \\
\text { genome }\end{array}$ & Sequence $\left(5^{\prime} \rightarrow 3^{\prime}\right)$ & $\begin{array}{c}\text { Amplicon } \\
\text { size }(\mathrm{bp})\end{array}$ \\
\hline BosD-F & V00654 & $15856-15887$ & CAATAACTCAACACAGAATTTGC & 300 \\
BosD-R & & $16135-16156$ & CGTGATCTAATGGTAAGGAATA & 444 \\
GoaD-F & AF533441 & $16043-16060$ & CCAACATGCGTATCCCGT & \\
GoaD-R & & $16468-16487$ & AGCGGATGCATGATGAAATG & \\
\hline
\end{tabular}

\section{MATERIALS AND METHODS}

\section{Study Design}

The study was performed in 2 stages. The first step was to standardize the PCR, including the assessment of different DNA extraction methods, and the determination of the limit detection of the PCR assay using different primer sets. The second step consisted of evaluating field bulk goat milk samples collected from smallholder producers in Paraíba, northeastern Brazil.

\section{Limit Detection Determination of the Duplex PCR}

To determine the analytical sensitivity of the PCR, dilutions of fresh goat milk were spiked with bovine milk at the concentrations of $0,0.1,0.5,1,5,10,50$, and $100 \%$. Deoxyribonucleic acid was extracted from the samples according to the following methods: 1) thermal extraction (Soumet et al., 1994), in which an aliquot of milk $(1 \mathrm{~mL})$ was centrifuged at $6,000 \times g$ for $15 \mathrm{~min}$ and then the supernatant was discarded and the sample diluted in $300 \mu \mathrm{L}$ of sterile distilled water and vortexed; the samples were incubated in a water bath at $100^{\circ} \mathrm{C}$ for $10 \mathrm{~min}$ and then centrifuged at 12,000 $\times g$ for $30 \mathrm{~s}$; the supernatant was collected and used as a DNA template; 2) phenol-chloroform extraction (Bania et al., 2001), in which aliquots of milk $(400 \mu \mathrm{L})$ were mixed with $200 \mu \mathrm{L}$ of digestion buffer consisting of Tris- $\mathrm{HCl}$ (200 mM, pH 8), $100 \mathrm{~m} M$ EDTA, 1\% SDS, and $60 \mu \mathrm{g}$ of proteinase $\mathrm{K}$; the mixture was incubated for $1 \mathrm{~h}$ at $55^{\circ} \mathrm{C}$ and then extracted twice with an equal volume of phenol-chloroform-isoamyl alcohol (25:24:1) and once with an equal volume of chloroform; after addition of $30 \mu \mathrm{L}$ of a $7.5 \mathrm{M}$ ammonium acetate solution, the DNA was precipitated with 2 volumes of ethanol and pelleted by centrifugation at $12,000 \times g$ for $2 \mathrm{~min}$. The precipitate was dried and dissolved again in TE buffer (10 mM Tris-HCl, pH 8 and $1 \mathrm{mM}$ EDTA); and 3) using a spin column kit (Invitek GmbH, Berlin, Germany) according to the manufacturer's instructions. The DNA extracted according to the 3 procedures was evaluated qualitatively and quantitatively using a biophotometer (BioPhotometer Plus; Eppendorf AG, Hamburg, Germany).

\section{DNA Amplification}

A duplex PCR (d-PCR) was standardized using the primer pairs BosD and GoaD (Bania et al., 2001; Kotowicz et al., 2007) for the simultaneous detection of bovine and goat DNA, respectively. The primers SIM-F, Boscytb-R, and Goacytb-R (Matsunaga et al., 1999) were also tested in a d-PCR. Detailed information about the primers, target sequence, and amplicon sizes are presented in Table 1.

The reaction mixture was prepared containing reaction buffer $1 \times, 1.5 \mathrm{mM} \mathrm{MgCl} 2,0.8 \mu \mathrm{mol} / \mathrm{L}$ of each bovine-specific primer and $0.2 \mu \mathrm{mol} / \mathrm{L}$ of each goatspecific primer, $0.2 \mathrm{mmol} / \mathrm{L}$ of each deoxyribonucleotide triphosphate (dNTP), 1 unit of Taq DNA polymerase, and $50 \mathrm{ng}$ of DNA to a final volume of $25 \mu \mathrm{L}$. The amplification was performed in a thermal cycler (TC3000, Techne Corp., Minneapolis, MN) and included 35 cycles of $95^{\circ} \mathrm{C}$ for $30 \mathrm{~s}, 52^{\circ} \mathrm{C}$ for $30 \mathrm{~s}$, and $72^{\circ} \mathrm{C}$ for $2 \mathrm{~min}$, with an initial denaturation step $\left(95^{\circ} \mathrm{C}\right.$ for $\left.10 \mathrm{~min}\right)$ and final extension at $72^{\circ} \mathrm{C}$ for $5 \mathrm{~min}$. The d-PCR products were separated by agarose gel electrophoresis (1.5\%) at 70 V. Specific bands was visualized under UV light after staining (GelRed; Biotium Inc., Hayward, CA).

\section{Validation of Duplex Assay Using Field Samples}

Samples of milk were collected from 160 dairy farmers in the semiarid region of Paraíba. Farms were randomly selected based on a previous list of farms in the region provided by the producer's association. Samples were kept on ice and transported to the laboratory for analysis. Duplex PCR was performed in triplicate for each sample.

\section{RESULTS}

Both the commercial spin column kit and the phenolchloroform extraction procedure provided similar results in terms of quality of extracted DNA from goat milk samples, with mean ratios of absorbance at 260 and 280 $\mathrm{nm}\left(\mathrm{A}_{260 / 280}\right.$ values $)$ of 1.53 and 1.63 , respectively. The $\mathrm{A}_{260 / 280}$ ratio value for the thermal extraction procedure was 1.2 . 
Amplification was achieved only with primer pairs BosD and GoaD (Bania et al., 2001; Kotowicz et al., 2007), even though primers SIM-F, Boscytb-R, and Goacytb-R were tested in different assay conditions. Thus, amplifications of field samples were carried out with the former primer sets.

The detection limit achieved by the d-PCR assay was $0.5 \%$ bovine milk in goat milk (Figure 1) using either the spin column kit or the phenol-chloroform extraction method. No amplification was detected when thermal extraction was used. In view of these results, the spin column kit was used in DNA extraction of field samples. The results of field samples showed that $66(41.2 \%)$ bulk goat milk samples produced by smallholders were adulterated with bovine milk.

\section{DISCUSSION}

The fact that no amplification was observed in PCR using thermal extraction indicates the inefficiency of this method in eliminating PCR inhibitors in milk. On the other hand, the spin column and phenol-chloroform extraction procedures provided better results, as expected. The efficacy of PCR is strongly related to the quantity and quality of DNA obtained from a given volume of milk, which depends on the effectiveness of the extraction protocol and abundance of somatic cells in milk. Because SCC in milk vary by species, breed,

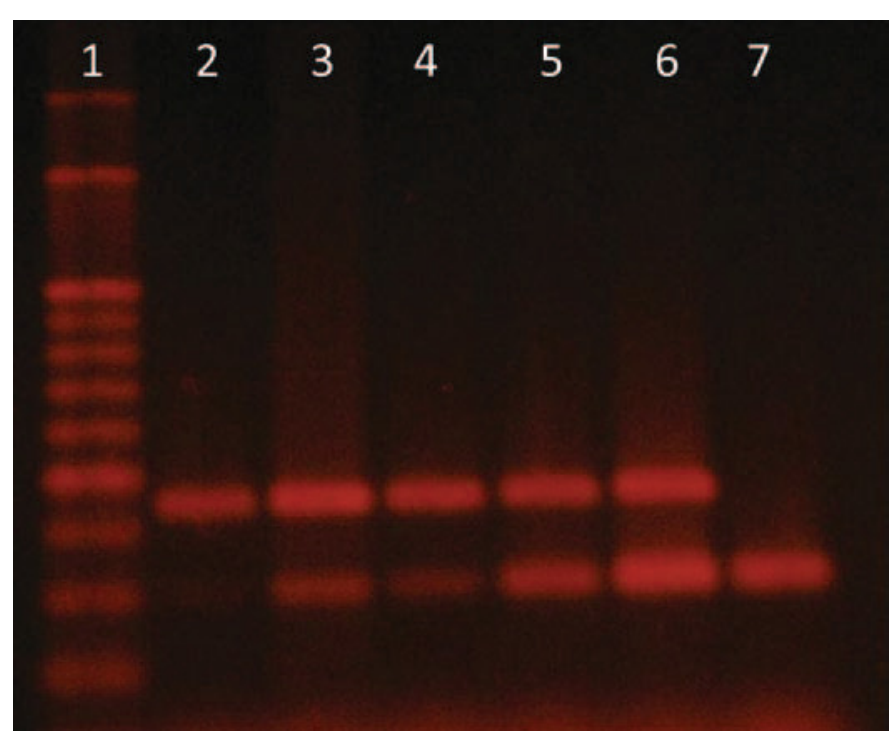

Figure 1. Agarose gel (1.5\%) showing amplicons produced by a duplex PCR (d-PCR) to detect bovine and goat milk simultaneously. Lane $1=100-$ bp molecular marker; lane $2=0.1 \%$ bovine milk; lane $3=0.5 \%$ bovine milk; lane $4=1 \%$ bovine milk; lane $5=10 \%$ bovine milk; lane $6=50 \%$ bovine milk; lane $7=100 \%$ bovine milk. Amplicons with 300 and $444 \mathrm{bp}$ correspond to bovine and caprine milk, respectively. Color version available in the online PDF. and the physiological state of animals, a consistent DNA-extraction method is required to ensure the PCR accuracy. The ease and rapidity of thermal extraction is counteracted by the low quantity of DNA effectively extracted, as original DNA sources (somatic cells) are diluted in the matrix (milk). Even if higher quantities of cells were present, apparently inhibitors were not eliminated and impaired the following steps.

The detection limit of bovine milk by the d-PCR was $0.5 \%$, which corroborates the results obtained by Kotowicz et al. (2007) using the same primer set. A multiplex PCR assay to detect milk from bovine, ovine, and caprine origin has been shown to detect $0.5 \%$ goat milk in such mixtures (Bottero et al., 2003). Although a lower analytical sensitivity $(0.1 \%$ bovine milk) was reported by Bai et al. (2009) using a uniplex PCR assay to detect milk from bovine origin in yak milk, no repeatability of the assay was observed in the present study in detecting $0.1 \%$ bovine milk in goat milk. Considering the wide range for somatic cells in goat milk, which is physiologically explained, larger numbers of goat somatic cells could lead to variations in the detection limits of PCR. Therefore, a detection limit of $0.5 \%$ bovine milk has been considered for the d-PCR used in the current study.

The low limit of detection result achieved in this study, together with the repeatability findings, suggest that the d-PCR can be successfully used to detect bovine milk adulteration of goat milk samples. Besides, considering the stability of DNA during thermal and acidification processes, PCR is considered a very promising method for species certification in products of animal origin. According to Mayer (2005), PCR-based methods are more appropriate than electrophoresis and chromatography to detect adulteration with bovine milk because of the thermal stability of DNA, even in heated and matured goat and sheep dairy products. A PCR-based assay was able to detect $0.5 \%$ bovine milk in Camembert cheese produced with ovine milk after 3 wk of maturation (Maudet and Taberlet, 2001). LópezCalleja Díaz et al. (2007) suggested that the PCR method is a valuable tool able to detect exogenous products in highly processed foods such as cheese, where the heat treatment, ripening, and preservation of samples may accelerate the degradation of DNA. Therefore, these results encourage the application of the PCR to investigate goat dairy products in the region as well, such as goat cheese, which comes from small-scale producers.

Although PCR seems a very promising tool for foodcertifying purposes, further studies are still required in order the make the PCR a reliable tool in certifying programs, as other variables could potentially influence its efficiency. For example, the primer set described by Matsunaga et al. (1999), which was originally designed 
for identification of mixtures of multiple species of meat but was successfully used in several studies for detection of milk from different species (Bottero et al., 2003; Mafra et al., 2004; López-Calleja et al., 2005; Kotowicz et al., 2007), showed very poor performance during the standardization of the assay in our laboratory. Such discrepancies could also be attributed to genetic differences in animal breeds, although PCR designed for species certification usually target conserved regions in the genome. Indeed, a predominance of native goat breeds exists in the investigated region and Bos taurus indicus cattle are commonly used in the region for production by smallholders. Therefore, further research is required to establish protocols for identification of the species origin of foods.

The analysis of bulk goat milk performed in this study by the d-PCR indicated a high rate $(41.2 \%)$ of adulteration of goat milk with bovine milk. This is plausible, as the majority of producers are smallholders who also raise cattle, and could be due to the variation in the profit margins of the different types of milk. The higher value of goat milk sales could be an incentive for adulteration among some farmers. Although the practice of adulteration is of great concern, and a risk to the producers' business, most producers do not know the real impact of the adulteration. In this case, educational efforts to clarify the risks of adulteration are required to ensure quality and safety of the product. Although we strongly believe that the presence of bovine milk was caused by adulteration for economic reasons, the unintentional presence of bovine and goat milk is also possible, considering that milking equipment is shared between the species.

This is not the first report about the presence of bovine milk in goat milk. Mafra et al. (2007) detected cow milk in goat milk cheeses in 15 of 17 samples collected commercially. The identification of the species origin of dairy products has become increasingly important with regard to enforcement of international health, fidelity of the information presented to the consumer, economics, and public health (Mininni et al., 2009).

\section{CONCLUSIONS}

This study reported the presence of bovine milk in goat milk produced by smallholders in Paraíba State, Brazil. Extension activities on good production practices and the availability of the d-PCR method for milk species certification in the goat production chain have been used to reduce adulteration and to ensure the species origin for goat milk produced by the association of producers.

\section{ACKNOWLEDGMENTS}

Our deepest thanks to the smallholder producers of goat milk in Paraíba who are striving to offer a betterquality product and to the associations of producers for trusting us with the task of orientation and training. We are also thankful to the National Council for Scientific and Technological Development (CNPq, Brasilia, Brazil, proc. 551971/2007-1) and to The Scientific and Technological Development Fund of The Bank of Northeastern Brazil (Fundeci/BNB) for supporting the project.

\section{REFERENCES}

Bai, W., W. Xu, K. Huang, Y. Yuan, S. Cao, and Y. Luo. 2009. A novel common primer multiplex PCR (CP-M-PCR) method for the simultaneous detection of meat species. Food Contr. 20:366-370.

Bania, J., M. Ugorski, A. Polanowski, and E. Adamczyk. 2001. Application of polymerase chain reaction for detection of goats' milk adulteration by milk of cow. J. Dairy Res. 68:333-336.

Bottero, M. T., T. Civera, D. Nucera, S. Rosati, P. Sacchi, and R. M. Turi. 2003. A multiplex polymerase chain reaction for the identification of cows', goats' and sheep's milk in dairy products. Int. Dairy J. 13:277-282.

Kotowicz, M., E. Adamczyk, and J. Bania. 2007. Application of a duplex-PCR for detection of cows' milk in goats' milk. Ann. Agric. Environ. Med. 14:215-218.

López-Calleja, I., I. González Alonso, V. Fajardo, M. A. Rodríguez, P. E. Hernández, T. García, and R. Martín. 2005. PCR detection of cows' milk in water buffalo milk and Mozzarella cheese. Int. Dairy J. 15:1122-1129.

López-Calleja Díaz, I., I. González Alonso, V. Fajardo, I. Martín, P. Hernández, T. García Lacarra, and R. M. de Santos. 2007. Application of a polymerase chain reaction to detect adulteration of ovine cheeses with caprine milk. Eur. Food Res. Technol. 225:345-349.

Mafra, I., I. M. P. L. V. O. Ferreira, M. A. Faria, and B. P. P. Oliveira 2004. A novel approach to the quantification of bovine milk in ovine cheeses using a duplex polymerase chain reaction method. J. Agric. Food Chem. 52:4943-4947.

Mafra, I., Á. Roxo, I. M. P. L. V. O. Ferreira, and M. B. P. P. Oliveira. 2007. A duplex polymerase chain reaction for the quantitative detection of cows' milk in goats' milk cheese. Int. Dairy J. $17: 1132-1138$.

Matsunaga, T., K. Chikuni, R. Tanabe, S. Muroya, K. Shibata, J. Yamada, and Y. Shinmura. 1999. A quick and simple method for the identification of meat species and meat products by PCR assay. Meat Sci. 51:143-148.

Maudet, C., and P. Taberlet. 2001. Detection of cows' milk in goats' cheeses inferred from mitochondrial DNA polymorphism. J. Dairy Res. 68:229-235.

Mayer, H. K. 2005. Milk species identification in cheese varieties using electrophoretic, chromatographic and PCR techniques. Int. Dairy J. $15: 595-604$

Mininni, A. M., C. Pellizzari, B. Cardazzo, L. Carraro, S. Balzan, and E. Novelli. 2009. Evaluation of real-time PCR assays for detection and quantification of fraudulent addition of bovine milk to caprine and ovine milk for cheese manufacture. Int. Dairy J. 19:617-623.

Soumet, C., G. Ermel, P. Fach, and P. Colin. 1994. Evaluation of different DNA extraction procedures for the detection of Salmonella from chicken products by polymerase chain reaction. Lett. Appl. Microbiol. 19:294-298. 